\title{
Enfermos egregios. Casos clínicos en que la historia es maestra
}

Como se ha reiterado en este foro recientemente ${ }^{1,2}$, la finalidad de los casos clínicos incluye la descripción de hallazgos infrecuentes o desconocidos de una enfermedad, presentaciones raras de entidades desconocidas, novedosas aproximaciones a procesos frecuentes, generación de hipótesis o información sobre efectos farmacológicos adversos no descritos o inusuales. Todo ello enmarcado en la educación médica continuada que mejora el entrenamiento de los profesionales de la salud, singularmente aquéllos en formación, para que proporcionen cuidados de calidad.

Como caso particular de tales supuestos clínicos, desde hace más de 20 años vengo divulgando las patobiografías de ciertas celebridades. Es decir, personajes conocidos, que, como decía el poeta Horacio, son humanos y por ello nada de lo humano les es ajeno, incluyendo la enfermedad y el dolor. En tales trabajos se intenta mostrar cómo nos legaron sus logros imperecederos, aun a pesar de sus padecimientos, o en ocasiones precisamente por ellos. Basta con evocar la obra de Frida Kahlo o Edvard Munch.

Oliver Sacks, el famoso neurólogo recientemente desaparecido, autor de retratos patobiográficos inolvidables, recogidos en libros tan inspiradores como El hombre que confundió a su mujer con un sombrero o Un antropólogo en Marte, declaró: "En el examen de la enfermedad, ganamos sabiduría sobre la anatomía, la fisiología y la biología. En el examen de la persona con enfermedad, ganamos sabiduría sobre la vida"s. Ello constituye gran verdad y en la exposición de sus casos se esfuerza en demostrar cómo, aun a pesar de padecimientos en ocasiones terriblemente despersonalizantes, los pacientes luchan por mantener su identidad.

Dichas celebridades son variadas y sus biografías sirven para resaltar determinados aspectos de los procesos mórbidos. Por ejemplo, el hecho de que nadie está exento de padecerlos. La trombosis venosa de Kate Winslet (conocida protagonista de Titanic) o el grave embolismo pulmonar puerperal de la tenista Serena Williams (2018) son paradigmáticos en este sentido. Otros, como la inesperada muerte de Andy Warhol ${ }^{4}$, en el posoperatorio de una colecistectomía, ocasionada por insuficiencia cardíaca precipitada, al parecer, por un poco cuidadoso balance hidroelectrolítico, muestran la fragilidad de la existencia y lo impredecible de la enfermedad en ocasiones, aunque nos previenen sobre la importancia de protocolos adecuados para evitar resultados adversos.

Otros casos nos permiten admirar la determinación del genio por crear, a pesar de las limitaciones impuestas por la enfermedad. La 9.a Sinfonía o el proyecto inconcluso de la 10.a a pesar de la cirrosis hepática de Beethoven; la agonía de Mozart en la uremia final de una probable glomerulonefritis postestreptocócica, y su empeño por terminar el Réquiem, constituyen señeros ejemplos 5 . También lo es el abandono de la escultura en piedra por Modigliani a causa del empeoramiento de su tuberculosis por la inhalación de polvo. Pero encontrando luminosos caminos alternativos en la pintura para crear sus sensuales madonas de cara ovalada. O Matisse, superando trabajosamente la debilidad derivada de complicaciones posoperatorias de un cáncer de colon y un embolismo pulmonar, para imaginar mediante el recorte de papeles multicolores sus célebres "Desnudos azules", de profunda influencia en el arte posterior ${ }^{6}$. El arte puede ocasionar dolor pero es a menudo tabla de salvación para tales artistas.

A veces tales casos clínicos históricos plantean desafíos dignos de los mejores "Case Reports" del New England, con desenlaces realmente sorprendentes. Por ejemplo, el planteado por la muerte de Pericles, el ilustre estratega ateniense, muerto en 429 a. C. por la "peste de Atenas", cabalmente descrita por Tucídides. De etiología largamente discutida (gripe, viruela, peste bubónica...), parece haberse aclarado verosímilmente al aislar ADN de Salmonella typhi en dientes de fallecidos por dicha entidad, procedentes del cementerio de Kerameikos? ${ }^{7}$ O la confirmación del saturnismo de Caravaggio, el violento y genial pintor barroco, al evidenciarse altos niveles de plomo en sus huesos, y la atribución definitiva de su muerte (Porto Ercole, Toscana italiana, 1610) a una sepsis por Staphilococcus aureus, al recuperar ADN de muestras dentarias del artista ${ }^{8}$. Anteriormente, su oscura muerte fue atribuida a brucelosis, sífilis, malaria, insolación...

Tal aproximación a personajes conocidos conlleva una ventaja sobre los tradicionales casos clínicos. Permiten muchas veces intuir sus creencias y pensamientos más íntimos. Incluyendo su actitud ante los médicos. Como tal me gustaría oír alguna vez a mis pacientes lo que Einstein decía de sus doctores. El físico, en cuanto científico desconfiaba ("los únicos diagnósticos en los que confío son los post-mortem") y, en cuanto paciente, era indisciplinado ("le gustan los médicos pero no las medicinas", observaba el Dr. Ehrmann), aunque como camarada fue siempre leal, defendiéndoles en ocasiones de ataques furibundos. Pues bien, acerca de la intervención sobre su aneurisma de aorta abdominal (en 1948, 6 años antes de su muerte), declaró que accedía a ella "tras una impresionante reunión con doctores [entre ellos el famoso cirujano Rudolf Nissen o el radiólogo Gustav Bucky] que son mis amigos"s.

Julio Montes-Santiago Servicio de Medicina Interna. Hospital Meixoeiro. Vigo (Pontevedra). España

Citar como: Montes-Santiago J. Enfermos egregios. Casos clínicos en que la historia es maestra. Rev Esp Casos Clin Med Intern (RECCMI). 2019 (Abr); 4(1): 1-2. doi: 10.32818/reccmi.a4n1a1. 


\section{Bibliografía}

1. García Alegría J. Razones para un caso clínico. Rev Esp Casos Clin Med Intern (RECCMI). 2017; 2: 105-106

2. Suárez-Fernández C. Aprendizaje a través de un caso clínico. Rev Esp Casos Clin Med Intern (RECCMI). 2018; 3: 105-106.

3. Sacks O. Un antropólogo en Marte. (Trad. Alou D). 12. a ed. Barcelona. Anagrama, 2015 (original, 1995).

4. Montes Santiago J. Crónica de una muerte inesperada. 25 años sin Andy Warhol. Med Clin (Barc). 2012; 139: 131-134.

5. Montes Santiago J. El coleccionista de cráneos célebres. Bilbao. Maturana, 2007
6. Montes Santiago J. Cuando el arte duele pero salva. Los casos de Modigliani, Matisse, Portinari y Rebecca Horn. Rev Clin Esp. 2013; 213: 208-211.

7. Papagrigorakis MJ, Yapijakis C, Synodinos PN, Baziotopoulou-Valavani E. DNA examination of ancient dental pulp incriminates typhoid fever as a probable cause of the Plague of Athens. Int J Infect Dis. 2006; 10: 206-214.

8. Drancourt M, Barbieri R, Cilli E, Gruppioni G, Bazaj A, Cornaglia G, Raoult D. Did Caravaggio die of Staphylococcus aureus sepsis? Lancet Infect Dis. 2018; 18: 1178. doi: 10.1016/S1473-3099(18)30571-1.

9. Montes Santiago J. Einstein como paciente. Historia de sus enfermedades y las relaciones con sus médicos. Barcelona. Bayer Healthcare, 2014. 